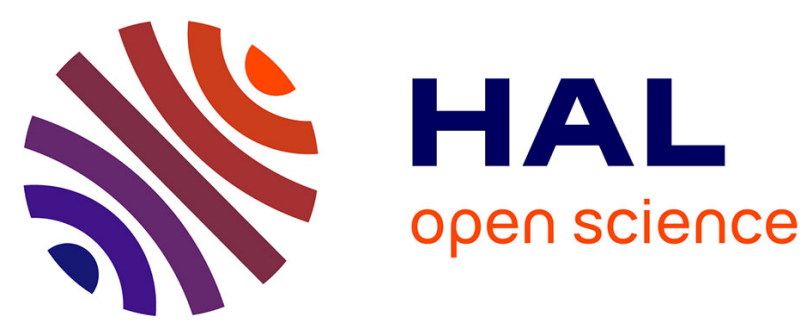

\title{
Relationships between structural characteristics of bovine intramuscular connective tissue assessed by image analysis and collagen and proteoglycan content Annabelle Dubost, Didier D. Micol, Bruno Meunier, Claire Lethias, Anne Listrat
}

\section{To cite this version:}

Annabelle Dubost, Didier D. Micol, Bruno Meunier, Claire Lethias, Anne Listrat. Relationships between structural characteristics of bovine intramuscular connective tissue assessed by image analysis and collagen and proteoglycan content. Meat Science, 2013, 93 (3), pp.378-386. 10.1016/j.meatsci.2012.09.020 . hal-02647008

\section{HAL Id: hal-02647008 \\ https://hal.inrae.fr/hal-02647008}

Submitted on 29 May 2020

HAL is a multi-disciplinary open access archive for the deposit and dissemination of scientific research documents, whether they are published or not. The documents may come from teaching and research institutions in France or abroad, or from public or private research centers.
L'archive ouverte pluridisciplinaire HAL, est destinée au dépôt et à la diffusion de documents scientifiques de niveau recherche, publiés ou non, émanant des établissements d'enseignement et de recherche français ou étrangers, des laboratoires publics ou privés. 


\title{
Relationships between structural characteristics of bovine intramuscular connective tissue assessed by image analysis and collagen and proteoglycan content
}

\author{
Annabelle Dubost ${ }^{\mathrm{a}}$, Didier Micol ${ }^{\mathrm{a}}$, Bruno Meunier ${ }^{\mathrm{a}}$, Claire Lethias ${ }^{\mathrm{b}}$, Anne Listrat ${ }^{\mathrm{a}, *}$ \\ a INRA (Institut National de la Recherche Agronomique), UMR1213 Herbivores, F-63122 Saint-Genès-Champanelle, France \\ b IBCP (Institut de Biologie et Chimie des Protéines), FRE 3310 DyHTIT, Passage du Vercors, 69367 Lyon, Cedex 07, France
}

\section{A R T I C L E I N F O}

Article history:

Received 3 May 2012

Received in revised form 12 September 2012

Accepted 19 September 2012

Available online 1 November 2012

\section{Keywords:}

Perimysium

Endomysium

Beef breed

Muscle

Collagen

Proteoglycans

\begin{abstract}
A B S T R A C T
Three muscles (Longissimus thoracis, Semimembranosus, Biceps femoris) of 40 young bulls from 3 breeds were used to quantify structural characteristics of bovine connective tissue by image analysis, with both macroscopic and microscopic approaches. Collagen and proteoglycan content was also investigated. Perimysium occupied a greater area ( 8 vs 6\%), and was wider (42 vs $2 \mu \mathrm{m}$ ) and shorter per unit area $\left(1.9 v s 30 \mathrm{~mm} \mathrm{~mm}^{-2}\right.$ ) than endomysium. Perimysium and endomysium from Longissimus were thinner, less ramified than in Biceps. Longissimus showed less total collagen and cross-linking and more proteoglycans $(P<0.0001)$ than Biceps muscle. Blond d'Aquitaine perimysium occupied less area, was more ramified and muscles contained less collagen, cross-linking and more proteoglycans than Angus $(P<0.001)$. Limousin was intermediate. High proteoglycan content in muscle containing less total collagen suggested a complementarity between these molecules. They might influence mechanical properties of intramuscular connective tissue. This was especially true given that proteoglycans and total collagen were negatively and positively linked with structural parameters, respectively. (c) 2012 Elsevier Ltd. All rights reserved.
\end{abstract}

\section{Introduction}

Connective tissue in skeletal muscle is divided into endomysium, surrounding each muscle fibre individually, perimysium surrounding groups of muscle fibres and epimysium surrounding the muscle as a whole. Intramuscular connective tissue (IMCT) (endomysium and perimysium) is a three-dimensional network whose morphology and composition varies from one type (species, gender, age) of animal to another and from one muscle to another according to muscle position and function, while having a complex link with meat tenderness (Purslow, 2005).

The first structural descriptions of IMCT were done manually and subjectively, by projection of stained muscle sections using an overhead projector (for large sections and muscle fibre bundle studies) or by microscopic observation (small sections and study of microscopic structures) (Dumont, 1982; Dumont \& Schmitt, 1973; Schmitt, Degas, Perot, Langlois, \& Dumont, 1979; Schmitt \& Dumont, 1969). More recently, image analysis associated with histological methods have been developed. Except Sifre-Maunier, Taylor, Berge, Culioli, and Bonny (2006) and Del Moral, O'Valle, Masseroli, and Del Moral (2007), authors have rarely described their method accurately. Image analysis has been used to study the structural characteristics of perimysium thickness (An et al., 2010; Brooks \& Savell, 2004; Das et al., 2010; Fang, Nishimura, \& Takahashi, 1999; Lachowicz, Zochowska, \& Sobczak, 2004; Nishimura, Fang, Wakamatsu, \& Takahashi, 2009; Sifre-Maunier

\footnotetext{
* Corresponding author.

E-mail address: anne.listrat@clermont.inra.fr (A. Listrat).
}

et al., 2006; Torrescano et al., 2001) or muscle fibre bundles, but few authors have been interested in endomysium (An et al., 2010; Lachowicz et al., 2004; Torrescano et al., 2001). This may be explained by the fact that the major part of the IMCT is perimysium (Light \& Champion, 1984; Light, Champion, Voyle, \& Bailey, 1985). Nevertheless, a negative correlation has been found between endomysium thickness and meat tenderness in breast muscle (Pectoralis superficialis and Pectoralis profundus) of chicken (An et al., 2010) and a positive correlation has been found in pork (Biceps femoris, Semimembranosus, Quadriceps femoris, Longissimus dorsi, all muscles combined) (Lachowicz et al., 2004). Therefore, the study of perimysium in conjunction with endomysium would seem important. We have developed an image analysis method and we have worked at two scales, macroscopic (magnification $\times 5$ ) and microscopic (magnification $\times 100$ ).

IMCT is mainly composed of fibrillar collagens embedded in a matrix of proteoglycans (PGs). These two classes of molecules form a continuous network inside perimysium but also between perimysium, endomysium and muscle fibres (Voermans et al., 2008). Fibrillar collagens make up the structure of IMCT and are linked between each other by different chemical cross-links. The main cross-links in muscle are the pyridinolines (hydroxylysylpyridinoline and dehydroxylysylpyridinoline). They are trivalent and thermo-stable. PGs play an important role in the stabilization of the intramuscular collagen network (Nishiumi, Fukuda, \& Nishimura, 1997), are sensitive to physiological changes (growth, age) (Nakano \& Scott, 1996; Rooney \& Kumar, 1993) and are quickly degraded by proteases during post-mortem storage (Nishimura, Hattori, \& Takahashi, 1996). The degradation of PGs during post-mortem ageing would expose collagen to collagenases and facilitate its degradation 
(Nishimura, Hattori, \& Takahashi, 1996). Thus, PGs could influence the mechanical properties of IMCT and tenderness. With regard to beef meat tenderness, proteoglycans have been little considered while collagen and its cross-links have been extensively studied and compared between muscles (Rhee, Wheeler, Shackelford, \& Koohmaraie, 2004; Torrescano, Sanchez-Escalante, Gimenez, Roncales, \& Beltran, 2003), but much less data exist between breeds. Nevertheless, it has been shown that muscularity affects the connective tissue structural parameters and its composition in collagen (Dumont, 1982; Listrat et al., 2001). In addition, late-maturing cattle breeds (as Belgian blue, Limousin and Blond d'Aquitaine) grow more slowly and deposit more muscles and less fat, compared to early-maturing cattle breeds (as Angus and Japanese Black cattle) which tend to have muscles richer in collagen with a higher proportion of insoluble collagen (Campo et al., 2000; Christensen et al., 2011; Jurie et al., 2011; Blanco et al., in press; Monson, Sanudo, \& Sierra, 2004).

The aim of the present study was to i) quantify structural characteristics of bovine IMCT (perimysium and endomysium) by image analysis, ii) show whether there was a relationship between these parameters and the biochemical composition of IMCT (collagen and PGs), and iii) determine which parameters best discriminate muscles and breeds.

\section{Materials and methods}

This study was carried out in compliance with the French recommendations and those of the Animal Care and Use Committee of the National Institute for Agricultural Research (INRA, Institut National de la Recherche Agronomique) of Clermont-Ferrand/Theix, France for the use of experimental animals including animal welfare.

\subsection{Beef production and muscle sampling}

The experiment was performed on 40 young entire males of Aberdeen Angus (AA) $(n=12)$, Limousin (LI) $(n=14)$ and Blond d'Aquitaine (BA) $(n=14)$ pure breeds. Animals ( 12 month-old) were assigned for a 100 day finishing period. The animals were housed in straw pens, individually fed and weighed every 2 weeks. Diets consisted of concentrate (75\%) and straw (25\%). Animals were slaughtered at the same age (around 17 months) and final live weight (around $665 \mathrm{~kg}$ ) (Table 1) in order to avoid weight and age effects on IMCT characteristics. They were slaughtered at the experimental slaughter-house of the INRA Research centre. For the other parameters (average daily gain, muscle and fat carcass characteristics), AA was significantly different to LI and BA, which were similar. AA had 17\% higher daily gain, 34\% higher fatty tissue weight and 19\% lower carcass muscle weight than LI and BA.

Three muscles were taken for each animal: Longissimus thoracis (LT), Semimembranosus (SM) and Biceps femoris (BF). For each muscle and each analysis, samples were taken at the same location. Muscle samples were removed from the 9th rib for LT and from the centre of the muscle for SM and BF.

For histological and PG measurements, muscle samples were taken 15 min after exsanguination. For histology, muscle samples of $1.5 \times 1.5 \times 1 \mathrm{~cm}$ were taken and for PG measurement, muscle samples $(60-80 \mathrm{~g})$ were cut up into small pieces. The two sets of samples were stored at $-80{ }^{\circ} \mathrm{C}$ until preparation for analysis. For histology, samples were initially frozen in isopentane chilled in liquid nitrogen.

The carcasses were chilled in a cold room $\left(+2{ }^{\circ} \mathrm{C}\right)$ and muscle samples were taken at $24 \mathrm{~h}$ post-mortem for collagen and cross-link measurements. Muscle samples (about $150 \mathrm{~g}$ ) were cut into pieces of $1 \mathrm{~cm}$ cross-section, sealed under vacuum in plastic bags and stored at $-20{ }^{\circ} \mathrm{C}$ until preparation for analysis.

\subsection{Histology associated with image analysis}

Muscle blocks $(1.5 \times 1.5 \times 1 \mathrm{~cm})$ were fixed with Tissue-Tek ${ }^{\circ} \mathrm{OCT}^{\mathrm{TM}}$ (Sakura) in a cryostat (HM $500 \mathrm{M}$, Microm, France) maintained at $-25{ }^{\circ} \mathrm{C}$, and cross-sections of $10 \mu \mathrm{m}$ thickness were prepared. For each animal, the three muscle sections were placed on the same slide. A total of 40 slides were stained. For each staining bath, the three breeds were mixed to limit staining differences between two staining baths. The staining was carried out according the Picro-Sirius red method previously described by Flint et al. (Flint \& Pickering, 1984) with slight modifications. Briefly, after acetone fixation (60 min), cross-sections were fixed $10 \mathrm{~min}$ in Picro-Formalin solution, rinsed in 90\% ethanol ( $1 \mathrm{~min})$, then in distilled water (10 $\mathrm{min})$ and immersed in Sirius red staining solution ( $60 \mathrm{~min}$ ) before washing in $0.01 \mathrm{M}$ hydrochloric acid ( $5 \mathrm{~min}$ ). After rinsing in distilled water $(1 \mathrm{~min})$, cross-sections were dehydrated successively in 95\% ethanol and then twice in 100\% ethanol. Stained sections were cleared in Safesolvant (Labonord) and mounted with Safemount (Labonord). IMCT (perimysium and endomysium) was stained red and muscle fibres yellow (dark grey and light grey, respectively, in Fig. 1). The aim was to create a contrast between IMCT and muscle fibres in order to develop an image analysis method to study perimysium, endomysium and muscle fibre morphology, on the same section, in an automatic and objective manner.

\subsubsection{Image acquisitions}

2.2.1.1. Perimysium study - macroscopy. Each stained muscle section $(1.5 \times 1.5 \mathrm{~cm})$ was scanned entirely in transmission mode using an EPSON Expression 10000XL PRO A3 scanner (resolution of $2400 \mathrm{dpi}$, corresponding to a spatial resolution of $10.58 \mu \mathrm{m} / \mathrm{pixel}$ ).

2.2.1.2. Endomysium study - microscopy. Stained sections were visualized in bright field mode with an Olympus BX51 microscope (Olympus, Tokyo, Japan) using a $10 \mathrm{x}$ objective $(\mathrm{NA}=0.3)$. Five images were acquired randomly from the stained sections of $1.5 \times 1.5 \mathrm{~cm}$, used for perimysium study, with a DP-72 colour camera and Cell-D image

Table 1

Finishing and slaughtering traits (mean, standard deviation [SD], Minimum, Maximum) of experimental animals.

\begin{tabular}{|c|c|c|c|c|c|c|c|c|c|c|c|c|c|}
\hline & \multicolumn{4}{|c|}{ Aberdeen Angus $(n=12)$} & \multicolumn{4}{|c|}{ Limousin $(n=14)$} & \multicolumn{4}{|c|}{ Blond d'Aquitaine $(\mathrm{n}=14)$} & \multirow[t]{2}{*}{$P$-value } \\
\hline & Mean & SD & Minimum & Maximum & Mean & SD & Minimum & Maximum & Mean & SD & Minimum & Maximum & \\
\hline Age at slaughter (mo) & 16.8 & 0.7 & 16.0 & 18.5 & 16.8 & 0.7 & 15.9 & 18.0 & 16.5 & 0.5 & 15.7 & 17.3 & 0.46 \\
\hline Final live weight (kg) & 689 & 50 & 607 & 784 & 659 & 32 & 580 & 718 & 645 & 53 & 543 & 744 & 0.06 \\
\hline Hot carcass weight (kg) & $385^{b}$ & 33 & 327 & 434 & $417^{\mathrm{a}}$ & 23 & 364 & 442 & $423^{a}$ & 41 & 356 & 500 & 0.01 \\
\hline Average daily gain $\left(\mathrm{g} \mathrm{d}^{-1}\right)$ & $1,697^{\mathrm{a}}$ & 214 & 1,429 & 2,161 & $1,347^{\mathrm{b}}$ & 164 & 1,029 & 1,609 & $1,460^{\mathrm{b}}$ & 366 & 811 & 1,876 & 0.01 \\
\hline $\begin{array}{l}\text { Carcass fatty tissues } \\
\text { weight }(\mathrm{kg})\end{array}$ & $73.7^{\mathrm{a}}$ & 14.5 & 51.4 & 93.1 & $51.5^{\mathrm{b}}$ & 4.9 & 44.5 & 61.1 & $45.0^{\mathrm{b}}$ & 8.1 & 28.3 & 57.1 & $<0.0001$ \\
\hline Carcass fat $(\%)$ & $19.1^{\mathrm{a}}$ & 3.0 & 14.8 & 22.8 & $12.4^{\mathrm{b}}$ & 1.0 & 11.0 & 14.1 & $10.6^{\mathrm{c}}$ & 1.5 & 8.0 & 13.4 & $<0.0001$ \\
\hline Muscles carcass weight (kg) & $256^{\mathrm{b}}$ & 22.2 & 223.0 & 304.5 & $311^{\mathrm{a}}$ & 18 & 270 & 332 & $322^{\mathrm{a}}$ & 31 & 279 & 387 & $<0.0001$ \\
\hline Muscle/Bone ratio & $4.64^{\mathrm{b}}$ & 0.18 & 4.25 & 4.92 & $5.75^{\mathrm{a}}$ & 0.20 & 5.46 & 6.13 & $5.73^{\mathrm{a}}$ & 0.16 & 5.46 & 5.98 & $<0.0001$ \\
\hline
\end{tabular}

${ }^{\mathrm{a}-\mathrm{b}}$ Within a row, means without a common superscript letter differ $(P<0.05)$. Means with no superscript letters are not significantly different. 


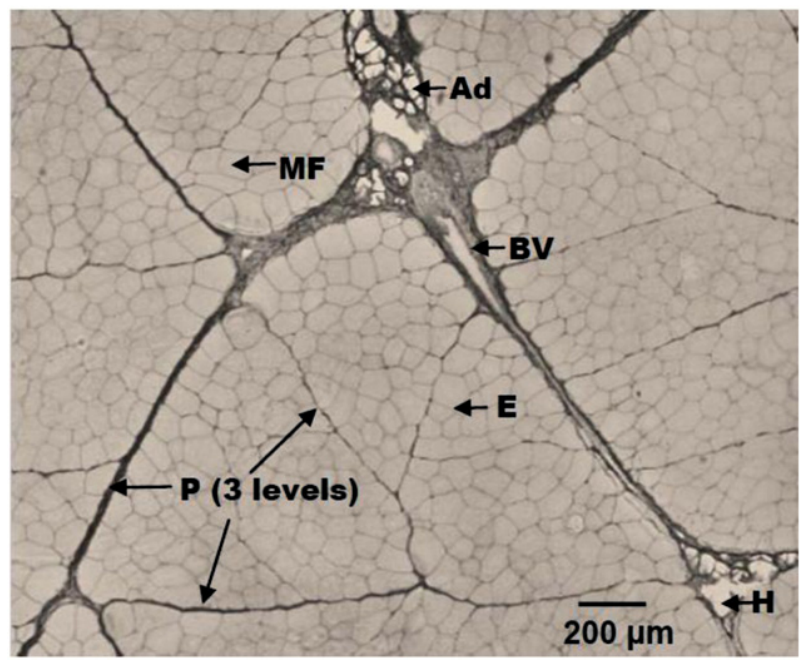

Fig. 1. Histological section of BF muscle stained according to the Picro-Sirius red method. Intramuscular connective tissue (P: perimysium and $\mathrm{E}$ : endomysium) appeared in dark grey and muscle fibres (MF) in light grey. Adipocytes (Ad) or holes (H) were not stained and appeared in white. The wall of blood vessels (BV) appeared in an intermediate level of grey.

acquisition software (Olympus Soft Imaging Solutions, Münster, Germany). The resolution was $1360 \times 1024$ pixels, representing an $879 \times 662 \mu \mathrm{m}$ field of view. The resulting spatial resolution was $0.65 \mu \mathrm{m} /$ pixel.
Both image acquisition strategies allowed a reliable control of geometrical (square pixel), colourimetric (white balance) and lighting (flatness and intensity) conditions. All colour images were saved in the uncompressed RGB-TIFF format.

\subsubsection{Image processing and analysis}

Image processing was realised under the Visilog 6.7 Professional Software (Noesis, Gif-sur-Yvette, France). This software provides fullaccess to a wide range of low-level precompiled image processing procedures. Indeed, it allows developing visual basic for application (VBA) programs to execute semi-automatically a specific algorithm, through a personalized user interface.

Two different VBA programs were developed: i) Perimysium Analyzer to study perimysium, and ii) Endomysium Fibre Analyzer to study endomysium and muscle fibres.

The different steps of the Perimysium Analyzer procedure are summarized in the flow chart (Fig. 2, A). Briefly, the colour image (Fig. 2B) was loaded and converted into greyscale RGB (Red, Green, Blue) and HLS (Hue, Luminance, Saturation) components. The more contrasted greyscale was selected for the following segmentation step. The Green component (Fig. 2C) was used for perimysium detection. Thin perimysium was identified by morphological tophat filtering and thick perimysium was segmented after manual thresholding. The saturation component (Fig. 2D) was used for sample detection (identification of muscle cells and perimysium from background) by automatic segmentation. These two segmentation steps resulted in binary image of perimysium (Fig. 2E) and of sample (Fig. 2F). After
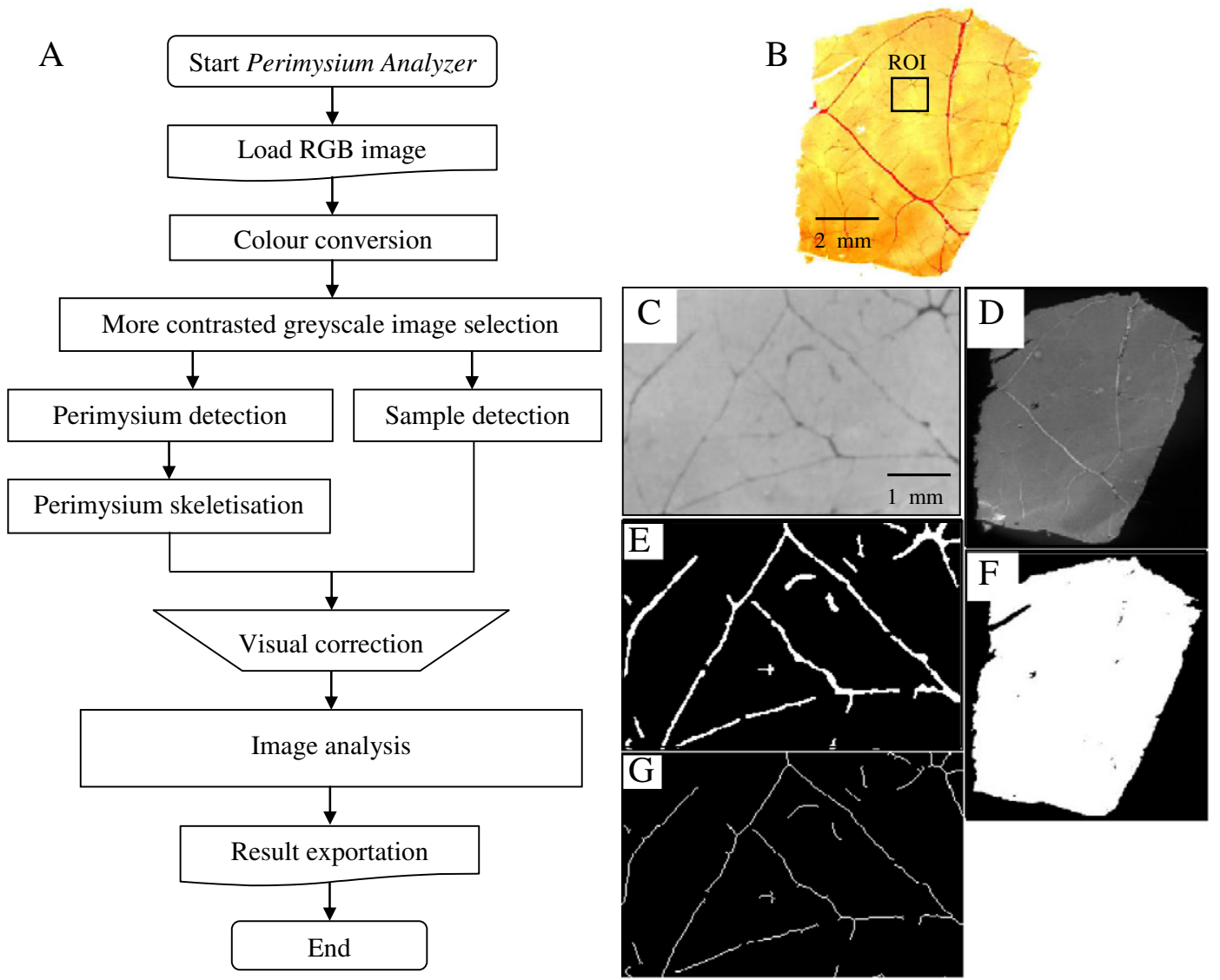

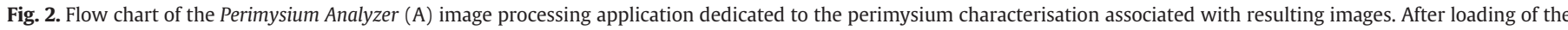

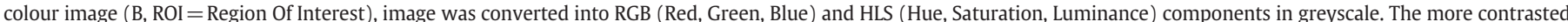

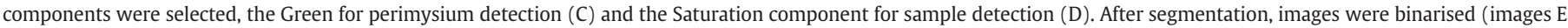

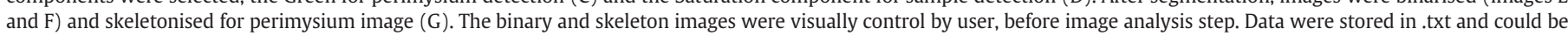
exported for further analysis. 
visual control of perimysium and sample segmentation, image analysis was initiated. Data of estimated parameters outlined below were stored in .txt and could be exported for further analysis.

The different steps of the Endomysium Fibre Analyzer procedure are summarized in a flow chart (Fig. 3A). The colour image (Fig. 3B) was loaded and converted into greyscale HLS components. The $\mathrm{H}$ component (Fig. 3C) was used for endomysial segmentation using fixed thresholding followed by watershed lines algorithm to close the network. This last step resulted in a separation of objects which correspond to the muscle fibres. We thus obtained the binary image of the endomysium (Fig. 3D) and the binary image of the muscle fibres (Fig. 3E). The binary image of the endomysium was skeletonised (Fig. 3F) and the binary image of fibres was labelled and filtered so that uncompleted fibres were automatically discarded (Fig. 3G). After visual control of endomysium segmentation, image analysis was initiated. Data of estimated parameters outlined below for endomysium and muscle fibre were stored in .txt and could be exported for further analysis.

For perimysium and endomysium study, the binarised images were used to determine the area of the perimysium and endomysium (both expressed as \% of the total image area). The skeletonised image was used to determine total length of perimysium and endomysium (both expressed in $\mathrm{mm} \mathrm{mm}^{-2}$ ) and triple points (named branch points for perimysium and connection points for endomysium, expressed as number $\mathrm{cm}^{-2}$ and as number $\mathrm{mm}^{-2}$, respectively). Indeed, two parameters were calculated for perimysium and endomysium: width (area/ total length, determined above for perimysium and endomysium respectively and expressed in $\mu \mathrm{m}$ for both) and length between 2 triple points (total length/triple point number, named unit length and expressed in $\mathrm{mm}$ for perimysium and in $\mu \mathrm{m}$ for endomysium). So, for all variables above, the comparison between perimysium and endomysium was relevant. For the muscle fibre study, the labelled images were used to determine the muscle fibre area (mean fibre area, expressed in $\mu \mathrm{m}^{2}$ ) and the number of muscle fibres per $\mathrm{mm}^{2}$. The processing algorithm classified fibres according to the number of sides. Three groups were formed; fibres with 3-4 sides, fibres with 5-6 sides and fibres with 7 sides or more, expressed in \%. The number of sides per muscle fibre was determined according to the connection points previously identified by algorithm ( 1 side was delineated by 2 connection points).

For endomysium and muscle fibre study, parameters obtained for the 5 acquired images of a muscle section were averaged.
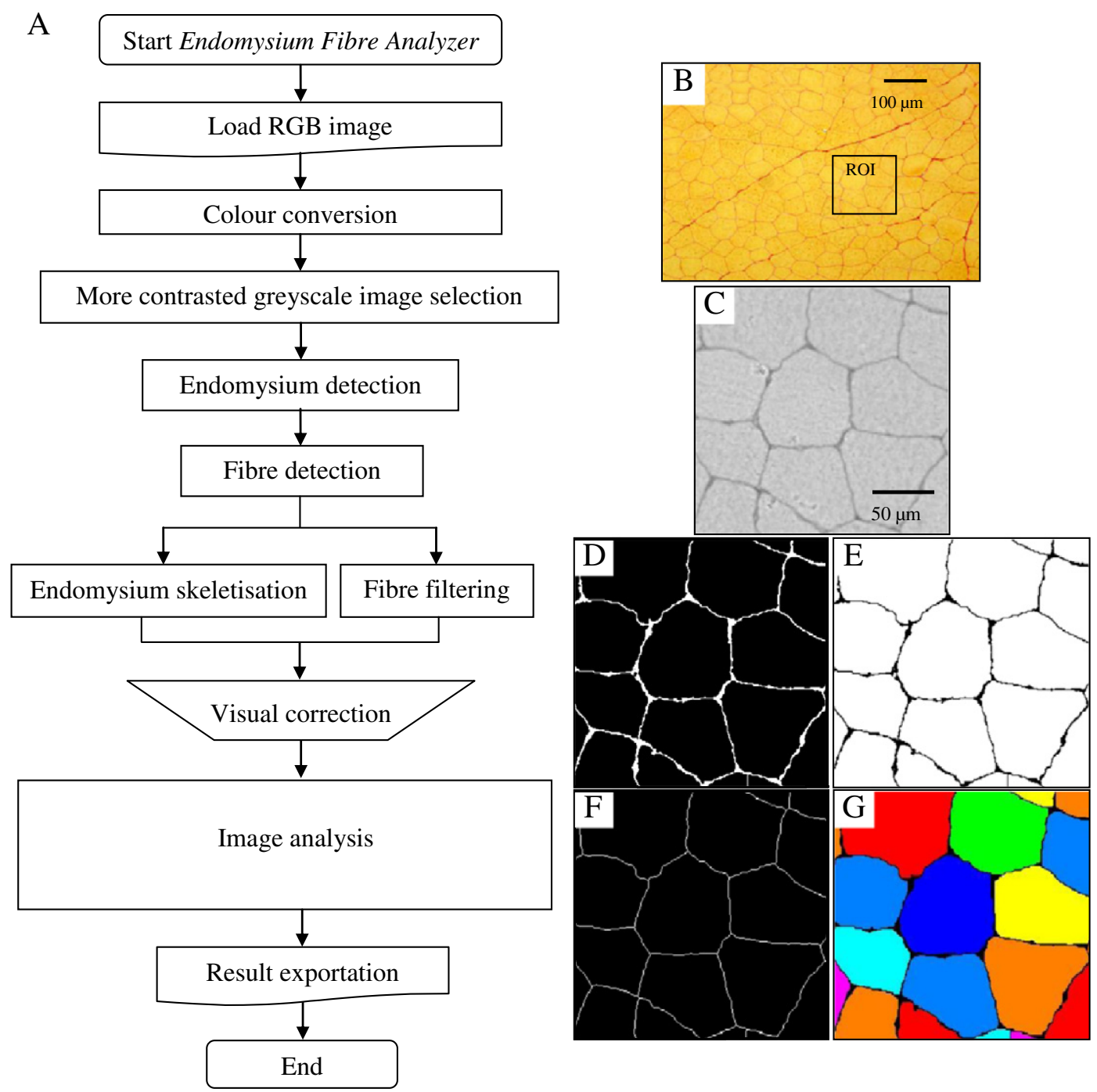

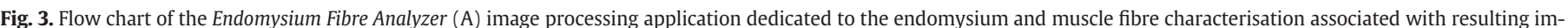

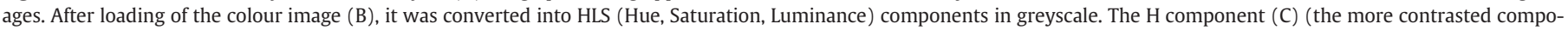

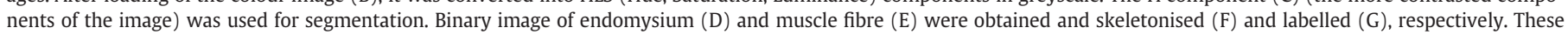
images ( $D$ to $G$ ) were used for image analysis step, after visual control by the user. Data were stored in .txt and could be exported for further analysis. 
For the perimysium study, the algorithm did not differentiate the different perimysium levels which surround different muscle fibre bundle levels. In our study, perimysium included 3 levels, from the perimysium surrounding primary fibre bundles to perimysium surrounding tertiary bundles (shown in Fig. 1). Moreover, lipids or holes (in white on Fig. 1) were not stained. So, during image processing they were not considered as belonging to the studied image.

\subsection{Biochemical characteristics of IMCT}

For total and insoluble collagen contents and cross-link measurements, frozen muscle was homogenized in a household cutter (Robot coupe $\AA, R 2$ ), freeze-dried for $48 \mathrm{~h}$, pulverized in a horizontal blade mill (Moulinex, type M CUA1) and stored at $+4{ }^{\circ} \mathrm{C}$ in stopper plastic flasks until analyses. For PG measurement, frozen muscles were powdered in liquid nitrogen and stored at $-80{ }^{\circ} \mathrm{C}$ until analyses.

\subsubsection{Collagen and cross-link measurements}

For total collagen (TC) and cross-links, about $250 \mathrm{mg}$ of muscle powder were weighed, acid hydrolysed with $10 \mathrm{~mL}$ of $6 \mathrm{~N} \mathrm{HCl}$, over-night at $110{ }^{\circ} \mathrm{C}$ in a screw-capped glass tube. For TC, the acid hydrolysate was diluted 5 times in $6 \mathrm{~N} \mathrm{HCl}$ and the subsequent procedure used was that previously described and updated by Listrat et al. (Listrat \& Hocquette, 2004; Listrat et al., 1999). For cross-links, $1 \mathrm{ml}$ of the $6 \mathrm{~N}$ acid hydrolysate was centrifuged at $16,000 \times \mathrm{g}$ for $5 \mathrm{~min}$ at $+4{ }^{\circ} \mathrm{C}$. For insoluble collagen (IC), muscle powder was solubilised according to the method of Hill (1966) as follows. Lyophilised muscle powder was rehydrated for one hour with $1 \mathrm{X}$ solubilization buffer $(0.23 \mathrm{M} \mathrm{NaCl}$, $25 \mathrm{mM}$ Tris- $\mathrm{HCl}, \mathrm{pH}$ 7.4) and heated in a water bath at $75{ }^{\circ} \mathrm{C}$ for one hour. The insoluble fraction was dissociated from the soluble fraction by filtration (pleated filters in cotton cellulose, VWR 512-0206) and hydrolysed according to the same method as for TC. Both for TC and IC, each sample was weighed and measured in triplicate and data were expressed in $\mathrm{mg}$ of collagen per $\mathrm{g}$ of dry matter ( $\left.\mathrm{mg} \mathrm{g}^{-1} \mathrm{DM}\right)$, assuming that collagen corresponds to $7.14 \times$ hydroxyproline content (Ngapo, Berge, Culioli, \& De Smet, 2002).

For cross-links, $600 \mu \mathrm{L}$ of $6 \mathrm{~N} \mathrm{NaOH}$ and $600 \mu \mathrm{L}$ of $1 \mathrm{M}$ Tris were added to $600 \mu \mathrm{L}$ of acid supernatant. Final $\mathrm{pH}$ was adjusted between 7 and 8 with a few microliters of $6 \mathrm{~N} \mathrm{HCl}$ or $\mathrm{NaOH}$. Pyridinoline cross-links (pyridinoline + deoxypyridinoline) were determined by the enzyme-linked immunoassay Metra Pyd EIA kit (Quidel Corporation, USA) according to the manufacturer. Previous assays had indicated no interfering effect of the $1 / 10$ diluted muscle extract on the pyridinoline cross-link determination (results not shown). Results were expressed in $\mathrm{nM}$ of pyridinoline per $\mathrm{g}$ of dry matter ( $\mathrm{nM}$ pyr $\mathrm{g}^{-1} \mathrm{DM}$ ) and per mole of collagen ( $\mathrm{mM}$ pyr $\mathrm{M}^{-1}$ collagen), assuming that collagen had a molecular weight of $300 \mathrm{kDa}$ ) (Ngapo et al., 2002).

\subsubsection{Total proteoglycan content}

Muscle powder was incubated $24 \mathrm{~h}$ at $+4{ }^{\circ} \mathrm{C}$ with extraction buffer ( $6 \mathrm{M}$ Urea, $1 \mathrm{M} \mathrm{NaCl}, 2 \%$ CHAPS and protease inhibitor cocktail [Complete, Roche Diagnostics GmbH, ref. 11836145 001]). The solid to liquid ratio was $100 \mathrm{mg}$ of muscle powder to $1 \mathrm{~mL}$ of extraction buffer. The next day, samples were centrifuged $40 \mathrm{~min}$ at $+4{ }^{\circ} \mathrm{C}$, $15,000 \times g$. Supernatant (muscle extract) was recovered and used to determine proteoglycan content according to a modified (Barbosa et al., 2003) Farndale method (Farndale, Sayers, \& Barrett, 1982). This assay was based on the ability of sulphated glycosaminoglycans (GAGs) to bind the cationic dye 1,9-dimethylmethylene blue (DMMB). Briefly, $1 \mathrm{~mL}$ of DMMB solution was added in excess to $100 \mu \mathrm{L}$ of muscle extract and shaken $30 \mathrm{~min}$ at room temperature. After centrifugation $15 \mathrm{~min}, 12,000 \times \mathrm{g}$, supernatant (DMMB excess) was removed. One $\mathrm{mL}$ of $50 \mathrm{mM}$ sodium acetate buffer solution was added to the residue and shaken $30 \mathrm{~min}$. Absorbance was measured at $656 \mathrm{~nm}$, with a micro-plate reader (TECAN Infinite ${ }^{\circledR}$ M200). Concentrations were determined by comparison with a standard curve of chondroitine- 4-sulfate (C4S), ranging from 0 to $2.5 \mu \mathrm{g}$ of C4S. Each sample was measured twice and data were expressed in $\mu \mathrm{g}$ of C4S-GAGs equivalents per $\mathrm{g}$ of dry matter ( $\mu \mathrm{g}$ C4S-GAGs $\mathrm{g}^{-1} \mathrm{DM}$ ) and in mg of C4S-GAGs per $\mathrm{g}$ of collagen (mg C4S-GAGs $\mathrm{g}^{-1}$ collagen).

\subsection{Statistical analysis}

Pearson correlation matrix was performed using XLSTAT-Pro (v. 2011.3.01) in order to study relationships between structural and biochemical variables. Then, data were subjected to analysis of variance using the SAS GLM procedure (Cary, NC: SAS Institute Inc.,). The fixed effects of muscle and breed type and muscle effect nested within animals were included in the model. Effect of muscle $\times$ breed interaction was also included in the model. The percentage of variance explained by this model was nearly the same as that of the model without muscle $\times$ breed interaction. The effects were mainly due to the muscle effect. So, we retained the model without muscle $\times$ breed interaction. Difference was claimed significant for $P<0.05$. All results were presented as LSmeans with appropriate standard error of the mean (SEM) and the level of significance.

\section{Results}

\subsection{Perimysium and endomysium distribution in muscle}

For all structural parameters in Table 2, the comparison between perimysium and endomysium was relevant because for both, the parameters were expressed in comparable units. Perimysium occupied $8 \%$ of the total image area and endomysium occupied $6 \%$. Perimysium

Table 2

Means, standard deviations (SD), coefficients of variation (CV), minimum and maximum of structural and biochemical parameters of IMCT and of muscle fibre $(n=120)$, across the three breeds and three muscles.

\begin{tabular}{|c|c|c|c|c|c|}
\hline & Mean & SD & $\mathrm{CV}(\%)$ & Minimum & Maximum \\
\hline \multicolumn{6}{|l|}{ Perimysium } \\
\hline Area (\%) & 8.0 & 2.4 & 29.8 & 3.8 & 16.1 \\
\hline Total length $\left(\mathrm{mm} \mathrm{mm}^{-2}\right)$ & 1.9 & 0.5 & 26.7 & 0.9 & 3.5 \\
\hline Width $(\mu \mathrm{m})$ & 42.4 & 3.4 & 8.0 & 34.5 & 51.5 \\
\hline Number of branch points $\mathrm{cm}^{-2}$ & 91 & 29 & 32.3 & 32 & 164 \\
\hline Unit length (mm) & 2.1 & 0.8 & 34.5 & 1.0 & 4.7 \\
\hline \multicolumn{6}{|l|}{ Endomysium } \\
\hline Area (\%) & 5.8 & 1.3 & 21.9 & 3.2 & 10.2 \\
\hline Total length $\left(\mathrm{mm} \mathrm{mm}^{-2}\right)$ & 30.0 & 2.5 & 8.4 & 24.2 & 35.5 \\
\hline Width $(\mu \mathrm{m})$ & 1.9 & 0.4 & 18.4 & 1.1 & 2.8 \\
\hline $\begin{array}{l}\text { Number of connection points } \\
\mathrm{mm}^{-2}\end{array}$ & 603 & 117 & 19.4 & 401 & 1227 \\
\hline Unit length $(\mu \mathrm{m})$ & 50.5 & 5.6 & 11.2 & 26.4 & 64.8 \\
\hline \multicolumn{6}{|l|}{ Muscle fibre } \\
\hline Fibre number $\mathrm{mm}^{-2}$ & 308 & 51 & 16.7 & 203 & 442 \\
\hline Mean fibre area $\left(\mu \mathrm{m}^{2}\right)^{\mathrm{a}}$ & 3336 & 560 & 16.9 & 2266 & 4783 \\
\hline Fibres with 3-4 sides (\%) & 18.7 & 5.2 & 27.9 & 5.0 & 37.1 \\
\hline Fibres with 5-6 sides (\%) & 53.9 & 7.2 & 13.3 & 38.3 & 79.0 \\
\hline Fibres with 7 sides (\%) & 27.4 & 5.4 & 19.9 & 4.6 & 43.2 \\
\hline \multicolumn{6}{|l|}{ Collagen } \\
\hline Total collagen ( $\left.\mathrm{mg} \mathrm{g}^{-1} \mathrm{DM}\right)$ & 39.7 & 11.5 & 29.0 & 21.0 & 74.6 \\
\hline Insoluble collagen ( $\left.\mathrm{mg} \mathrm{g}^{-1} \mathrm{DM}\right)$ & 26.7 & 7.3 & 27.3 & 14.3 & 49.0 \\
\hline \multicolumn{6}{|l|}{ Cross-linking } \\
\hline Cross-links ( $\mathrm{nM}$ pyr $\mathrm{g}^{-1} \mathrm{DM}$ ) & 27.9 & 10.2 & 36.5 & 13.9 & 70.2 \\
\hline $\begin{array}{l}\text { Cross-links (mM pyr } \mathrm{M}^{-1} \\
\text { collagen) }\end{array}$ & 210 & 34 & 16.4 & 144 & 325 \\
\hline \multicolumn{6}{|l|}{ Proteoglycans } \\
\hline $\begin{array}{l}\text { Total proteoglycan } \\
\quad\left(\mu \mathrm{g} \text { C4S-GAGs g }{ }^{-1} \mathrm{DM}\right)\end{array}$ & 491 & 151 & 30.7 & 221 & 903 \\
\hline $\begin{array}{l}\text { Total proteoglycan } \\
\quad\left(\mathrm{mg} \text { C4S-GAGs } \mathrm{g}^{-1} \text { collagen }\right)\end{array}$ & 14.1 & 8.1 & 57.4 & 4.2 & 41.3 \\
\hline
\end{tabular}


had an area 1.4 times higher than endomysium. However, per $\mathrm{mm}^{2}$, perimysium was 15 times shorter than endomysium ( 1.9 vs $30 \mathrm{~mm}$ ) and 22 times wider (42.4 vs $1.9 \mu \mathrm{m})$. Per $\mathrm{mm}^{2}$, endomysium had 603 connection points. The length (unit length) between two points was on average $50 \mu \mathrm{m}$. Per $\mathrm{cm}^{2}$, perimysium network had 91 branch points. The distance between two branch points was on average $2.1 \mathrm{~mm}$ (unit length). Our results also showed 308 muscle fibres per $\mathrm{mm}^{2}$ with an average cross-sectional area of 3,336 $\mu \mathrm{m}^{2}$ (equivalent to a circle with a diameter of $65.2 \mu \mathrm{m}$ ). Muscle had a majority of fibres with 5-6 sides (54\%).

Table 3 summarizes the correlations between the structural and biochemical parameter studied. The structural parameters were positively correlated to each other. Correlations between area and total length or width for perimysium and endomysium, respectively, were particularly significant (ranged from 0.50 to $0.97, P<0.05$ ). The structural parameters were also positively correlated with total and insoluble collagen content and cross-link (significant correlations ranged from 0.19 to 0.56 ). The above parameters were negatively correlated with PGs (significant correlations of -0.48 with total collagen and crosslinks and -0.50 with perimysium area and length). Fibre number, endomysium length and connection points were negatively correlated with fibre area $(r=-0.98,-0.41$ and -0.44 , respectively). Within muscles or breeds, correlations similar to those in Table 3 between structural and biochemical variables were found (results not shown).

Table 2 showed that, with the exception of perimysium width ( $C V=8 \%)$ and total endomysium length ( $8.4 \%$ of variation), all parameters were highly variable, probably due to muscle and breed variations. CVs of structural parameters ranged from 11.2 to $34.5 \%$. CVs of biochemical parameters ranged from 16.4 to $58 \%$.

\subsection{Muscle effect on structural and biochemical parameters}

Table 4 showed that 21 of 22 parameters (except perimysium unit length) had a $P$-value of 0.001 or less. Parameters which differed significantly between the 3 muscles were, among structural parameters, perimysium area (expressed in \%) and width, and among biochemical parameters, total and insoluble collagen, cross-links expressed per $g$ of DM and PGs expressed per $g$ of collagen. The other parameters (endomysium and muscle fibre) differed significantly between LT, SM and BF. LT showed respectively 30 and 35\% less perimysium area than SM and BF muscles. The same pattern was observed in the endomysium area, LT endomysium area was $26 \%$ lower than for SM and $\mathrm{BF}$ muscles. LT perimysium was $25 \%$ shorter and $10 \%$ narrower than SM and BF, whereas endomysium was $4 \%$ shorter and $24 \%$ narrower. BF perimysium showed significantly more branch points than LT (98 vs 84 branch points $\mathrm{cm}^{-2}$ ) and SM was intermediate.
Table 4

Muscle effect on structural (perimysium, endomysium, muscle fibre) and biochemical (collagen, cross-links, proteoglycans) characteristics of muscles.

\begin{tabular}{|c|c|c|c|c|c|}
\hline & \multicolumn{3}{|l|}{ Muscle $^{\mathrm{d}}$} & \multirow[b]{2}{*}{ SEM } & \multirow[b]{2}{*}{$P$-value } \\
\hline & $\begin{array}{l}\text { LT } \\
(n=40)\end{array}$ & $\begin{array}{l}\mathrm{SM} \\
(\mathrm{n}=40)\end{array}$ & $\begin{array}{l}\mathrm{BF} \\
(\mathrm{n}=40)\end{array}$ & & \\
\hline \multicolumn{6}{|l|}{ Perimysium } \\
\hline Area (\%) & $6.0^{c}$ & $8.6^{\mathrm{b}}$ & $9.2^{\mathrm{a}}$ & 0.3 & $<0.0001$ \\
\hline Total length $\left(\mathrm{mm} \mathrm{mm}^{-2}\right)$ & $1.5^{\mathrm{b}}$ & $2.0^{\mathrm{a}}$ & $2.1^{\mathrm{a}}$ & 0.1 & $<0.0001$ \\
\hline Width $(\mu \mathrm{m})$ & $39.4^{\mathrm{c}}$ & $43.0^{\mathrm{b}}$ & $44.8^{\mathrm{a}}$ & 0.4 & $<0.0001$ \\
\hline Number of branch points $\mathrm{cm}^{-2}$ & $84^{\mathrm{b}}$ & $90^{\mathrm{ab}}$ & $98^{\mathrm{a}}$ & 5 & $<0.0001$ \\
\hline Unit length (mm) & 1.8 & 2.2 & 2.1 & 0.1 & 0.07 \\
\hline \multicolumn{6}{|l|}{ Endomysium } \\
\hline Area (\%) & $4.7^{\mathrm{b}}$ & $6.3^{\mathrm{a}}$ & $6.4^{\mathrm{a}}$ & 0.2 & $<0.0001$ \\
\hline Total length $\left(\mathrm{mm} \mathrm{mm}^{-2}\right)$ & $29.1^{\mathrm{b}}$ & $30.5^{\mathrm{a}}$ & $30.3^{\mathrm{a}}$ & 0.4 & $<0.0001$ \\
\hline Width $(\mu \mathrm{m})$ & $1.6^{\mathrm{b}}$ & $2.1^{\mathrm{a}}$ & $2.1^{\mathrm{a}}$ & 0.04 & $<0.0001$ \\
\hline $\begin{array}{l}\text { Number of connection points } \\
\mathrm{mm}^{-2}\end{array}$ & $545^{\mathrm{b}}$ & $630^{\mathrm{a}}$ & $619^{a}$ & 15 & $<0.0001$ \\
\hline Unit length $(\mu \mathrm{m})$ & $53.4^{\mathrm{a}}$ & $48.6^{\mathrm{b}}$ & $49.5^{\mathrm{b}}$ & 0.8 & $<0.0001$ \\
\hline \multicolumn{6}{|l|}{ Muscle fibre } \\
\hline Fibre number $\mathrm{mm}^{-2}$ & $288^{\mathrm{b}}$ & $324^{\mathrm{a}}$ & $314^{\mathrm{a}}$ & 8 & 0.0006 \\
\hline Mean fibre area $\left(\mu \mathrm{m}^{2}\right)$ & $3591^{\mathrm{a}}$ & $3164^{\mathrm{b}}$ & $3253^{\mathrm{b}}$ & 84 & 0.0002 \\
\hline Fibres with 3-4 sides (\%) & $16.2^{\mathrm{b}}$ & $19.2^{\mathrm{a}}$ & $20.1^{\mathrm{a}}$ & 0.6 & $<0.0001$ \\
\hline Fibres with 5-6 sides (\%) & $59.2^{\mathrm{a}}$ & $52.6^{\mathrm{b}}$ & $50.7^{\mathrm{b}}$ & 0.8 & $<0.0001$ \\
\hline Fibres with 7 sides (\%) & $24.6^{\mathrm{b}}$ & $28.2^{\mathrm{a}}$ & $29.2^{\mathrm{a}}$ & 0.7 & $<0.0001$ \\
\hline \multicolumn{6}{|l|}{ Collagen } \\
\hline Total collagen ( $\left.\mathrm{mg} \mathrm{g}^{-1} \mathrm{DM}\right)$ & $29.6^{\mathrm{c}}$ & $39.1^{\mathrm{b}}$ & $50.6^{\mathrm{a}}$ & 1.2 & $<0.0001$ \\
\hline $\begin{array}{l}\text { Insoluble collagen } \\
\left(\mathrm{mg} \mathrm{g}^{-1} \mathrm{DM}\right)\end{array}$ & $21.6^{\mathrm{c}}$ & $25.6^{\mathrm{b}}$ & $32.9^{\mathrm{a}}$ & 0.9 & $<0.0001$ \\
\hline \multicolumn{6}{|l|}{ Cross-linking } \\
\hline Cross-links (nM pyr $\mathrm{g}^{-1} \mathrm{DM}$ ) & $19.0^{c}$ & $28.2^{\mathrm{b}}$ & $36.6^{\mathrm{a}}$ & 1.0 & $<0.0001$ \\
\hline $\begin{array}{l}\text { Cross-links (mM pyr } \mathrm{M}^{-1} \\
\text { collagen) }\end{array}$ & $195^{\mathrm{b}}$ & $218^{\mathrm{a}}$ & $216^{\mathrm{a}}$ & 5 & 0.001 \\
\hline \multicolumn{6}{|l|}{ Proteoglycans } \\
\hline $\begin{array}{l}\text { Total proteoglycan } \\
\qquad\left(\mu \mathrm{g} \mathrm{C} 4 \mathrm{~S}-\mathrm{GAGs} \mathrm{g}^{-1} \mathrm{DM}\right)\end{array}$ & $629^{a}$ & $416^{\mathrm{b}}$ & $429^{b}$ & 17 & $<0.0001$ \\
\hline $\begin{array}{l}\text { Total proteoglycan } \\
\quad(\mathrm{mg} \text { C4S-GAGs g } \\
-1 \\
\text { collagen) }\end{array}$ & $22.6^{\mathrm{a}}$ & $10.9^{\mathrm{b}}$ & $8.9^{c}$ & 0.7 & $<0.0001$ \\
\hline
\end{tabular}

${ }^{\mathrm{a}-\mathrm{c} W i t h i n}$ a row, means without a common superscript letter differ $(P<0.05)$. Means with no superscript letters are not significantly different.

${ }^{\mathrm{d}} \mathrm{LT}=$ Longissimus thoracis, $\mathrm{SM}=$ Semimembranosus, $\mathrm{BF}=$ Biceps femoris

Length between two branch points was not significantly different ( $2 \mu \mathrm{m}$ on average). These two parameters were relative to degree of ramification. LT had lower muscle fibre density (288 fibres $\mathrm{mm}^{-2}$ ) and fibres had cross-sectional area $11 \%$ greater than BF and SM muscle fibres. It had a higher proportion of fibres with 5-6 sides and a

Table 3

Correlation coefficients ${ }^{a}$ between structural and biochemical parameters ${ }^{b}(n=120)$, across the three breeds and three muscles.

\begin{tabular}{|c|c|c|c|c|c|c|c|c|c|c|c|c|c|c|}
\hline & Area_P & Lgth_P & Wdth_P & $\mathrm{BP}$ & Area_E & Lgth_E & Wdth_E & $\mathrm{CP}$ & FbreNber & Area_F & CL_DM & TC & IC & PG_DM \\
\hline Area_P & 1 & & & & & & & & & & & & & \\
\hline Lgth_P & 0.97 & 1 & & & & & & & & & & & & \\
\hline Wdth_P & 0.50 & 0.26 & 1 & & & & & & & & & & & \\
\hline $\mathrm{BP}$ & 0.33 & 0.37 & -0.01 & 1 & & & & & & & & & & \\
\hline Area_E & 0.50 & 0.45 & 0.35 & 0.16 & 1 & & & & & & & & & \\
\hline Lgth_E & 0.37 & 0.36 & 0.15 & 0.14 & 0.45 & 1 & & & & & & & & \\
\hline Wdth_E & 0.51 & 0.47 & 0.34 & 0.06 & 0.61 & 0.14 & 1 & & & & & & & \\
\hline $\mathrm{CP}$ & 0.39 & 0.36 & 0.23 & 0.13 & 0.51 & 0.93 & 0.22 & 1 & & & & & & \\
\hline FbreNber & 0.24 & 0.21 & 0.18 & 0.004 & 0.41 & 0.41 & 0.29 & 0.43 & 1 & & & & & \\
\hline Area_F & -0.24 & -0.22 & -0.19 & -0.003 & -0.41 & -0.41 & -0.26 & -0.44 & -0.98 & 1 & & & & \\
\hline CL_DM & 0.54 & 0.47 & 0.45 & 0.19 & 0.56 & 0.18 & 0.51 & 0.25 & 0.23 & -0.26 & 1 & & & \\
\hline $\mathrm{TC}$ & 0.55 & 0.46 & 0.50 & 0.25 & 0.53 & 0.18 & 0.49 & 0.25 & 0.17 & -0.18 & 0.77 & 1 & & \\
\hline IC & 0.45 & 0.39 & 0.38 & 0.18 & 0.41 & 0.10 & 0.44 & 0.17 & 0.14 & -0.13 & 0.65 & 0.81 & 1 & \\
\hline PG_DM & -0.50 & -0.50 & -0.27 & -0.25 & -0.40 & -0.25 & -0.36 & -0.30 & -0.19 & 0.22 & -0.48 & -0.48 & -0.41 & 1 \\
\hline
\end{tabular}

a Correlation coefficient values in bold are significant for $P<0.05$.

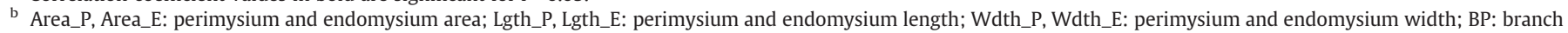

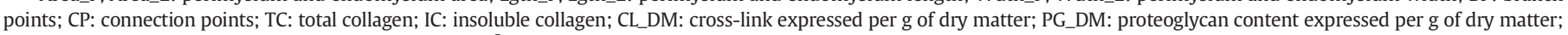
Area_F: mean fibre area; FbreNber: fibre number per $\mathrm{mm}^{2}$. 
lower proportion of fibres with 3-4 and 7 sides. The average length of LT fibre sides was longer $(53.4 \mu \mathrm{m})$ than that of SM and BF muscles (48.6 and $49.5 \mu \mathrm{m}$ respectively).

LT muscle had 24 and $42 \%$ less total collagen content than SM and BF, respectively. Insoluble collagen content was lower in LT muscle than in $\mathrm{SM}$ and $\mathrm{BF}$ (17 and 35\% less, respectively). Cross-link content was $41 \%$ lower in LT than in SM and BF and PG content was 33\% greater in LT than in SM and BF. Expressed relative to total collagen, LT cross-link content was only $10 \%$ lower and PG content $57 \%$ greater than in SM and BF.

\subsection{Breed effect on structural and biochemical parameters}

Table 5 showed that 11 of 23 parameters had a $P$-value for breed effects of at least $\leq 0.001$. Several perimysium characteristics (area, total length and branch point number) and the proportion of muscle fibres with 5-6 sides differed significantly between the breeds. Percentage of fibres with 3-4 sides discriminated AA from the others breeds, while percentage of fibres with 7 sides differed between BA and the others breeds.

The other structural parameters did not allow differentiating breeds. AA perimysium area (9.5\% of the total image area) was 17 and 29\% higher than in LI and BA (7.9 and 6.7\% respectively). In AA, endomysium had an area $14 \%$ higher than BA (LI was not significantly different from AA and BA). AA showed 14\% longer perimysium and 5\% longer endomysium than BA. Perimysium of LI was different from AA and $\mathrm{BA}$ and endomysium was similar to $\mathrm{AA}$ and $\mathrm{BA}$. AA perimysium

\section{Table 5}

Breed effect on structural (perimysium, endomysium, muscle fibre) and biochemical (collagen, cross-links, proteoglycans) characteristics of muscle $(n=120)$.

\begin{tabular}{|c|c|c|c|c|c|}
\hline & \multicolumn{3}{|l|}{ Breed $^{\mathrm{d}}$} & \multirow[b]{2}{*}{ SEM } & \multirow[b]{2}{*}{$P$-value } \\
\hline & $\begin{array}{l}\mathrm{AA} \\
(\mathrm{n}=36)\end{array}$ & $\begin{array}{l}\mathrm{LI} \\
(\mathrm{n}=42)\end{array}$ & $\begin{array}{l}\mathrm{BA} \\
(\mathrm{n}=42)\end{array}$ & & \\
\hline \multicolumn{6}{|l|}{ Perimysium } \\
\hline Area $(\%)$ & $9.5^{\mathrm{a}}$ & $7.9^{\mathrm{b}}$ & $6.7^{\mathrm{c}}$ & 0.3 & $<0.0001$ \\
\hline Total length $\left(\mathrm{mm} \mathrm{mm}^{-2}\right)$ & $2.2^{\mathrm{a}}$ & $1.9^{\mathrm{b}}$ & $1.6^{\mathrm{c}}$ & 0.1 & $<0.0001$ \\
\hline Width ( $\mu \mathrm{m})$ & 42.2 & 41.7 & 43.3 & 0.5 & 0.07 \\
\hline Number of branch points $\mathrm{cm}^{-2}$ & $95^{\mathrm{b}}$ & $109^{a}$ & $69^{c}$ & 4 & $<0.0001$ \\
\hline Unit length (mm) & $2.5^{\mathrm{a}}$ & $1.8^{\mathrm{b}}$ & $2.5^{\mathrm{a}}$ & 0.1 & 0.0004 \\
\hline \multicolumn{6}{|l|}{ Endomysium } \\
\hline Area $(\%)$ & $6.4^{\mathrm{a}}$ & $5.7^{\mathrm{ab}}$ & $5.5^{\mathrm{b}}$ & 0.2 & 0.01 \\
\hline Total length $\left(\mathrm{mm} \mathrm{mm}^{-2}\right)$ & $30.7^{\mathrm{a}}$ & $30.1^{\mathrm{ab}}$ & $29.1^{\mathrm{b}}$ & 0.4 & 0.04 \\
\hline Width $(\mu \mathrm{m})$ & 2.0 & 1.9 & 1.9 & 0.1 & 0.16 \\
\hline $\begin{array}{l}\text { Number of connection points } \\
\mathrm{mm}^{-2}\end{array}$ & 630 & 590 & 579 & 16 & 0.14 \\
\hline Unit length ( $\mu \mathrm{m})$ & 49.3 & 51.7 & 50.3 & 0.9 & 0.10 \\
\hline \multicolumn{6}{|l|}{ Muscle fibre } \\
\hline Fibre number $\mathrm{mm}^{-2}$ & 317 & 308 & 301 & 8 & 0.53 \\
\hline Mean fibre area $\left(\mu \mathrm{m}^{2}\right)$ & 3244 & 3336 & 3416 & 89 & 0.53 \\
\hline Fibres with 3-4 sides (\%) & $15.4^{\mathrm{b}}$ & $18.8^{\mathrm{a}}$ & $21.3^{\mathrm{a}}$ & 0.9 & 0.0003 \\
\hline Fibres with 5-6 sides (\%) & $58.2^{\mathrm{a}}$ & $54.8^{\mathrm{b}}$ & $49.4^{c}$ & 0.9 & $<0.0001$ \\
\hline Fibres with 7 sides (\%) & $26.4^{\mathrm{b}}$ & $26.3^{\mathrm{b}}$ & $29.4^{\mathrm{a}}$ & 0.9 & 0.04 \\
\hline \multicolumn{6}{|l|}{ Collagen } \\
\hline Total collagen ( $\left.\mathrm{mg} \mathrm{g}^{-1} \mathrm{DM}\right)$ & $46.9^{\mathrm{a}}$ & $37.3^{\mathrm{b}}$ & $36.1^{\mathrm{b}}$ & 1.7 & $<0.0001$ \\
\hline $\begin{array}{l}\text { Insoluble collagen } \\
\left(\mathrm{mg} \mathrm{g}^{-1} \mathrm{DM}\right)\end{array}$ & $31.1^{\mathrm{a}}$ & $25.2^{\mathrm{b}}$ & $24.5^{\mathrm{b}}$ & 1.1 & $<0.0001$ \\
\hline \multicolumn{6}{|l|}{ Cross-linking } \\
\hline Cross-links (nM pyr $\left.\mathrm{g}^{-1} \mathrm{DM}\right)$ & $33.0^{\mathrm{a}}$ & $26.5^{\mathrm{b}}$ & $25.0^{\mathrm{b}}$ & 1.5 & 0.0002 \\
\hline $\begin{array}{l}\text { Cross-links } \\
\quad\left(\mathrm{mM} \text { pyr } \mathrm{M}^{-1} \text { collagen }\right)\end{array}$ & 208 & 214 & 207 & 6 & 0.68 \\
\hline \multicolumn{6}{|l|}{ Proteoglycans } \\
\hline $\begin{array}{l}\text { Total proteoglycan } \\
\qquad\left(\mu \mathrm{g} \text { C4S-GAGs } \mathrm{g}^{-1} \mathrm{DM}\right)\end{array}$ & $437^{\mathrm{b}}$ & $478^{\mathrm{b}}$ & $552^{\mathrm{a}}$ & 22 & 0.001 \\
\hline $\begin{array}{l}\text { Total proteoglycan } \\
\quad\left(\mathrm{mg} \text { C4S-GAGs g }{ }^{-1} \text { collagen) }\right.\end{array}$ & $10^{\mathrm{c}}$ & $14.6^{\mathrm{b}}$ & $17.2^{\mathrm{a}}$ & 1.1 & $<0.0001$ \\
\hline
\end{tabular}

$\overline{\mathrm{a}-\mathrm{c} W i t h i n \text { a row, means without a common superscript letter differ }(P<0.05) \text {. Means }}$ with no superscript letters are not significantly different.

${ }^{\mathrm{d}} \mathrm{AA}=$ Aberdeen Angus, $\mathrm{LI}=$ Limousin, $\mathrm{BA}=$ Blond d'Aquitaine. was more ramified than BA (95 vs 69 branch points) but they had the same unit length $(2.5 \mathrm{~mm})$. LI had more branch points (109) than AA and BA and a shorter distance between 2 points $(1.8 \mathrm{~mm})$.

Among biochemical parameters, PGs (expressed per $g$ of collagen) distinguished the 3 breeds from each other while collagen characteristics (total, insoluble and cross-links in nM pyr $\mathrm{g}^{-1} \mathrm{DM}$ ) demonstrated that AA was different from LI and BA. Cross-link content (expressed per $g$ of DM) was $22 \%$ higher in AA than in LI and BA. Reported to the total collagen content, cross-link content was not significantly different between the 3 breeds. PG content was 17\% higher for BA than AA and LI. Reported to the total collagen content, BA had 14 and 42\% higher PG content than LI and AA, respectively.

\section{Discussion}

In image analysis, two constraints emerged. The first one concerned the sampling representativeness linked to the field of view and the second the detailed characterisation linked to the resolution. To take into account perimysium heterogeneity, we chose a macroscopic approach by scanning the whole section $(1.5 \times 1.5 \mathrm{~cm})$. For accurate characterisation of endomysium and muscle fibre, we needed for a microscopic approach. This two scale approach proved efficient for an automatic and accurate characterisation of IMCT components. Ideally, it would be interesting to contain all information in a unique image. To this end, a mosaic image containing several hundred megabytes could be acquired under the microscope. Unfortunately, these bulky images are still impossible to automatically analyze and visualize today.

Several authors have attempted to characterize perimysium but, up to now only its area and width have been studied in several species. Table 6 summarizes the characteristics of intramuscular connective tissue previously studied. In pork, Del Moral et al. (2007) showed a LT perimysium area of 22.6 and $9.9 \%$ (\% of the total image area) respectively for Large White crossbreed and Iberian pigs and LT perimysium area ranged from 3\% for Bos Taurus Rubia Gallega to 5.8\% for Kobe beef. The same authors (Del Moral et al., 2007) also showed for sheep a perimysium area of 13.8 and $20.7 \%$ (\% of the total image area) respectively for Triceps brachii and LT. Sifre-Maunier et al. (2006) showed, for 5-year-old Charolais cull cows, a perimysium area ranging from 3.1 to $14 \%$ in LT muscle, for a threshold confidence level of 0.80 and 0.55 (the former allowing the thicker perimysium detection and the latter allowing overall perimysium detection), respectively. BF perimysium area ranged from 4.9 to $13.8 \%$. For perimysium width, Torrescano et al. (2001) determined the perimysium thickness surrounding the first and the second level of muscle fibre bundles. In cattle, data ranged from 30 to $120 \mu \mathrm{m}$, in sheep from 10 to $30 \mu \mathrm{m}$ and in goat from 10 to $20 \mu \mathrm{m}$. Sifre-Maunier et al. (2006) determined a cattle perimysium width ranged from 58 to $74 \mu \mathrm{m}$ for LT and reached $82 \mu \mathrm{m}$ for BF bovine muscle. In pork, Lachowicz et al. (2004) determined an average perimysium width (average of LT, SM and BF) of 15 and $20 \mu \mathrm{m}$ respectively for domestic piglets and wild boar juveniles. Results obtained for Landrace pigs (Fang et al., 1999; Nishimura et al., 2009) showed an average perimysium width (perimysium surrounding secondary bundles) of $24 \mu \mathrm{m}$ for 6 month pigs. In chicken, Das et al. (2010) showed a perimysium width for broilers ( 8 weeks) ranging from $30 \mu \mathrm{m}$ (thick perimysium) to $10 \mu \mathrm{m}$ (thin perimysium). An et al. (2010) determined a perimysium width for chicks ( 6 to 18 weeks) ranging from $14 \mu \mathrm{m}$ to $39 \mu \mathrm{m}$. Finally, Torrescano et al. (2001) determined an endomysial thickness of $10 \mu \mathrm{m}$ in goat and sheep and of $15 \mu \mathrm{m}$ in cattle. Lachowicz et al. (2004) determined a width of $1.7 \mu \mathrm{m}$ in piglets and $2.3 \mu \mathrm{m}$ in wild juvenile boars (average of LT, SM and BF muscles). An et al. (2010) showed a width ranging from 5 to $8 \mu \mathrm{m}$ for $6-18$ week chicks.

On average in this study, perimysium area was $8 \%$ and perimysium width was $42 \mu \mathrm{m}$. Our data are consistent with cattle results above taking into account that observation scales are different from one study to another and that for perimysium thickness it is sometimes difficult to 
Table 6

Overview of characteristics of perimysium and endomysium measured by image analysis.

\begin{tabular}{|c|c|c|c|c|c|}
\hline \multirow[t]{2}{*}{ Reference } & \multirow[t]{2}{*}{ Species } & \multirow[t]{2}{*}{ Muscle $^{a}$} & \multicolumn{3}{|c|}{ Connective tissue characteristics } \\
\hline & & & $\begin{array}{l}\text { perimysial area } \\
\text { (\% of the total image area) }\end{array}$ & $\begin{array}{l}\text { perimysial width } \\
(\mu \mathrm{m})\end{array}$ & $\begin{array}{l}\text { endomysial width } \\
(\mu \mathrm{m})\end{array}$ \\
\hline \multirow[t]{3}{*}{ Current results } & Bovine & LT & 6 & 39.4 & 4.7 \\
\hline & $(\mathrm{n}=40$, for each muscle) & SM & 8.6 & 43.0 & 6.3 \\
\hline & & $\mathrm{BF}$ & 9.2 & 44.8 & 6.4 \\
\hline \multirow[t]{5}{*}{ Del Moral et al. (2007) } & $\begin{array}{l}\text { Pig } \\
(n=5)\end{array}$ & LT & 9.9 to 22.6 & - & - \\
\hline & $\begin{array}{l}\text { Bos Taurus Rubia Gallaga } \\
(\mathrm{n}=5)\end{array}$ & LT & 3.0 & - & - \\
\hline & $\begin{array}{l}\text { Kobe beef } \\
(n=5)\end{array}$ & LT & 5.8 & - & - \\
\hline & Sheep & TB & 13.8 & - & - \\
\hline & $(n=5)$ & LT & 20.7 & - & - \\
\hline \multirow[t]{2}{*}{ Sifre-Maunier et al. (2006) } & Bovine & LT & 3.1 to 14 & 58 to 74 & - \\
\hline & ( $\mathrm{n}=8$, for each muscle) & $\mathrm{BF}$ & 4.9 to 13.8 & 82 & - \\
\hline \multirow[t]{3}{*}{ Torrescano et al. (2001) } & Bovine & SM & - & 30 to 120 & 15 \\
\hline & Sheep & & - & 10 to 30 & 10 \\
\hline & Goat & & - & 10 to 20 & 10 \\
\hline \multirow[t]{3}{*}{ Lachowicz et al. (2004) } & Domestic piglet & LT, & - & 15 & 1.7 \\
\hline & $(\mathrm{n}=10$, for each muscle $)$ & SM, & & & \\
\hline & $\begin{array}{l}\text { Wild boar juvenile } \\
\text { ( } n=10 \text {, for each muscle) }\end{array}$ & $\mathrm{BF}$ & - & 20 & 2.3 \\
\hline $\begin{array}{l}\text { Fang et al. (1999) } \\
\quad \text { Nishimura et al. (2009) }\end{array}$ & Pig & $\begin{array}{l}\text { ST }(n=3) \\
\text { LT, ST }(n=4)\end{array}$ & - & 24 & - \\
\hline Das et al. (2010) & $\begin{array}{l}\text { Chicken } \\
(n=6)\end{array}$ & PT & - & 10 to 30 & - \\
\hline An et al. (2010) & $\begin{array}{l}\text { Chicken } \\
(\mathrm{n}=60)\end{array}$ & breast muscle & - & 14 to 39 & 5 to 8 \\
\hline
\end{tabular}

${ }^{\mathrm{a}} \mathrm{LT}=$ Longissimus thoracis, $\mathrm{SM}=$ Semimembranosus, $\mathrm{BF}=$ Biceps femoris, $\mathrm{TB}=$ Triceps brachii, $\mathrm{PT}=$ Pectoralis, $\mathrm{ST}=$ Semitendinosus.

determine which level was considered. However, cattle perimysial area appears to be lower than perimysial area in pig and sheep. Perimysial thickness appears to be greater in cattle than in pig and chicken maybe because of the higher level of organization in the perimysium of cattle.

Except perimysium width, total length of endomysium, the mean values of all structural and biochemical descriptors presented a high variation. This probably reflects the functional differences of the muscles, since LT is a positional muscle and SM and BF are locomotion muscles. According to the functional requirements of muscle (contraction, elongation), quantity, spatial distribution and composition of IMCT vary in order to coordinate force transmission in muscle (Purslow, 2010). During locomotion, functional effort is greater than during posture resulting in different perimysium and endomysium characteristics for the different muscle types. Thus, LT muscle perimysium was less ramified (number of branch points), shorter and thinner than BF muscle perimysium which had a higher perimysium area, total length and was more ramified. The same tendency was found for LT muscle endomysium, which was narrower, shorter and had fewer connection points than BF muscle.

LT muscle contained less collagen than BF, and SM was intermediate. These results are in agreement with those of others authors (Rhee et al., 2004; Stolowski et al., 2006; Torrescano et al., 2003). One of the other main components of muscle is proteoglycans (PGs). The LT muscle contained the most PGs. LT perimysium area was lower than $\mathrm{BF}$ perimysium area. Collagen fibrils are used as a scaffold for the anchorage of PGs which link collagen fibrils together in order to stabilize the collagenous network and to maintain space between fibrils (Eggen, Pedersen, Lea, \& Kolset, 2001). So, more PG in the IMCT could result in a greater space between collagen fibrils, and of a dilution by PGs.

In meat tenderness context, PGs are not often considered. However, they seem to play an important role in the process of meat ageing. Nishimura, Hattori, and Takahashi (1996) have shown that PGs are degraded during post-mortem ageing of beef. This degradation involves the separation of collagen fibrils and muscle fibres from endomysium and perimysium. In addition, microscopic studies have shown that a fracture line first appears between the collagen fibres at the level of some collagen-PG interactions when tension is applied perpendicularly to the myofibres in meat (Purslow, 1985). PGs are sensitive to enzymatic digestion resulting in an exposure of collagen fibrils to degradation by collagenases during ageing and therefore to an IMCT disorganization (Nishimura, 2010). LT muscle had a PG/collagen ratio (total PGs expressed in $\mathrm{mg}^{\mathrm{C}} 4 \mathrm{~S}-\mathrm{GAGs}^{-1}$ collagen) higher than that of BF muscle. These results are in accordance with the studies of Pedersen, Kolset, Sorensen, and Eggen (1999) and Eggen et al. (2001) which showed that Psoas major muscle, a muscle very poor in collagen (Torrescano et al., 2003), had a higher PG/collagen ratio than Semitendinosus, a muscle rich in collagen (Torrescano et al., 2003). In addition, it has been suggested that with fewer PGs available to form a network around the collagen fibres, the formation of cross-linkages in collagen could increase (Pedersen et al., 1999). Our results confirmed this suggestion since we showed greater cross-link content in BF muscle containing fewer PGs, compared to LT muscle, and a negative relationship between PG content and insoluble collagen and cross-link contents. Our results are in agreement with those of the other authors and suggest that there may be a balance between PG, collagen and cross-link contents, which could affect meat tenderness during ageing.

The cattle breed might also impact the deviation shown on almost all the descriptors, but breed effect was lower than muscle effect, as already shown (Schreurs et al., 2008). The BA breed had a less ramified and shorter perimysium and muscles had fewer total and insoluble collagen. On the contrary, the Angus breed had a more ramified and longer perimysium with a higher area, and higher total and insoluble collagen content. For structural parameters LI were intermediate, while for total and insoluble collagen, they were not different from BA. This difference of content in total collagen between Limousin and Angus has already been shown (Christensen et al., 2011; Jurie et al., 2011). In a previous study, we showed that BA had a high muscularity (Listrat et al., 2001). This particularity is often associated with a modification of structural characteristics (Dumont, 1982) and of 
content in total and insoluble collagen (Christensen et al., 2011; Jurie et al., 2011; Monson et al., 2004; Oliván et al., 2004).

The BA animals showed also more PGs (relative to the total collagen) than $\mathrm{LI}$ and $\mathrm{AA}$, and the three breeds were the same cross-link content, expressed per mole of collagen. The assumption that there is a balance between PG, collagen and cross-link contents seems to be confirmed for the breed. Nonetheless, the relationship between PGs and cross-links (more PG and less cross-link) is less clear, because cross-link content was not significantly different between the three breeds.

\section{Conclusion}

The image analysis method developed here allowed to quickly quantifying intramuscular connective tissue characteristics at different muscle levels. The positive correlations between structural IMCT descriptors and collagen content suggested that histology associated with image analysis could replace biochemical measurements, which are long and sometimes tedious to implement.

The high PG content in muscle containing less total collagen suggested a complementarity between these molecules and they might play a role on the mechanical properties of IMCT and perhaps on meat quality. This was especially true given that PGs and total collagen were negatively and positively link with structural parameters, respectively.

\section{Acknowledgements}

The authors express their thanks to the staff of INRA Experimental Unit (UERT) for animal management and slaughtering, and the staff of the 'Animal, Muscle, Viande' team for technical assistance, particularly Jean-Luc Montel and David Chadeyron for the collagen and cross-link content measurements, and Christiane Barboiron for her pertinent advice for the PG study.

\section{References}

An, J. Y., Zheng, J. X., Li, J. Y., Zeng, D., Qu, L. J., Xu, G. Y., et al. (2010). Effect of myofiber characteristics and thickness of perimysium and endomysium on meat tenderness of chickens. Poultry Science, 89(8), 1750-1754.

Barbosa, I., Garcia, S., Barbier-Chassefiere, V., Caruelle, J. P., Martelly, I., \& Papy-Garcia, D. (2003). Improved and simple micro assay for sulfated glycosaminoglycans quantification in biological extracts and its use in skin and muscle tissue studies. Glycobiology, 13(9), 647-653.

Brooks, J. C., \& Savell, J. W. (2004). Perimysium thickness as an indicator of beef tenderness. Meat Science, 67(2), 329-334.

Campo, M. M., Santolaria, P., Sanudo, C., Lepetit, J., Olleta, J. L., Panea, B., et al. (2000). Assessment of breed type and ageing time effects on beef meat quality using two different texture devices. Meat Science, 55(4), 371-378.

Christensen, M., Ertbjerg, P., Failla, S., Sanudo, C., Richardson, R. I., Nute, G. R., et al. (2011) Relationship between collagen characteristics, lipid content and raw and cooked texture of meat from young bulls of fifteen european breeds. Meat Science, 87(1), 61-65.

Das, C., Roy, B. C., Oshima, I., Miyachi, H., Nishimura, S., Iwamoto, H., et al. (2010). Collagen content and architecture of the pectoralis muscle in male chicks and broilers reared under various nutritional conditions. Animal Science Journal, 81(2), 252-263.

Del Moral, F. G., O'Valle, F., Masseroli, M., \& Del Moral, R. G. (2007). Image analysis application for automatic quantification of intramuscular connective tissue in meat. Journal of Food Engineering, 81(1), 33-41.

Dumont, B. L. (1982). Carcass composition and muscle structure in hypertrophied animals. In J. W. B. King, \& F. Ménissier (Eds.), Current topics in veterinary medicine and animal science (pp. 111-136).

Dumont, B. L., \& Schmitt, O. (1973). Conséquences de l'hypertrophie musculaire héréditaire sur la trame conjonctive du muscle de bovin. Annales de Génétique et de Sélection Animale, 5(4), 499-506.

Eggen, K. H., Pedersen, M. E., Lea, P., \& Kolset, S. O. (2001). Structure and solubility of collagen and glycosaminoglycans in two bovine muscles with different textural properties. Journal of Muscle Foods, 12(4), 245-261.

Fang, S. H., Nishimura, T., \& Takahashi, K. (1999). Relationship between development of intramuscular connective tissue and toughness of pork during growth of pigs. Journal of Animal Science, 77(1), 120-130.

Farndale, R. W., Sayers, C. A., \& Barrett, A. J. (1982). A direct spectrophotometric micro-assay for sulfated glycoaminoglycans in cartilage cultures. Connective Tissue Research, 9(4), 247-248.

Flint, F. O., \& Pickering, K. (1984). Demonstration of collagen in meat-products by an improved picro-sirius red polarization method. Analyst, 109(11), 1505-1506.
Hill, F. (1966). The solubility of intramuscular collagen in meat animals of various ages. Journal of Food Science, 31(2), 161-166.

Jurie, C., Picard, B., Micol, D., Listrat, A., Kammoun, M. \& Hocquette, J. F. (2011). Muscle characteristics from young bulls of different beef breeds. In, 57th ICoMST, M. Science (Ed.) (pp. 243-324). Ghent, Belgique.

Lachowicz, K., Zochowska, J., \& Sobczak, M. (2004). Comparison of the texture and structure of selected muscles of piglets and wild boar juveniles. Polish Journal of Food and Nutrition Sciences, 13(1), 75-79.

Light, N., \& Champion, A. E. (1984). Characterization of muscle epimysium, perimysium and endomysium collagens. Biochemical Journal, 219(3), 1017-1026.

Light, N., Champion, A. E., Voyle, C., \& Bailey, A. J. (1985). The role of epimysial, perimysial and endomysial collagen in determining texture in 6 bovine muscles. Meat Science, 13(3), 137-149.

Listrat, A., \& Hocquette, J. F. (2004). Analytical limits of total and insoluble collagen content measurements and of type i and iii collagen analysis by electrophoresis in bovine muscles. Meat Science, 68(1), 127-136.

Listrat, A., Picard, B., Jailler, R., Collignon, H., Peccatte, J. R., Micol, D., et al. (2001). Grass valorisation and muscular characteristics of blonde d'aquitaine steers. Animal Research, 50(2), 105-118.

Listrat, A., Rakadjiyski, N., Jurie, C., Picard, B., Touraille, C., \& Geay, Y. (1999). Effect of the type of diet on muscle characteristics and meat palatability of growing salers bulls. Meat Science, 53(2), 115-124.

Blanco, M., Jurie, C., Micol, D., Agabriel, J., Picard, B., \& Garcia-Launay, F. (in press). Impact of animal and management factors on collagen characteristics in beef: A review. Animal.

Monson, F., Sanudo, C., \& Sierra, I. (2004). Influence of cattle breed and ageing time on textural meat quality. Meat Science, 68(4), 595-602.

Nakano, T., \& Scott, P. G. (1996). Changes in the chemical composition of the bovine temporomandibular joint disc with age. Archives of Oral Biology, 41(8-9), 845-853.

Ngapo, T. M., Berge, P., Culioli, J., \& De Smet, S. (2002). Perimysial collagen crosslinking in belgian blue double-muscled cattle. Food Chemistry, 77(1), 15-26.

Nishimura, T. (2010). The role of intramuscular connective tissue in meat texture. Animal Science Journal, 81(1), 21-27.

Nishimura, T., Fang, S., Wakamatsu, J. -I., \& Takahashi, K. (2009). Relationships between physical and structural properties of intramuscular connective tissue and toughness of raw pork. Animal Science Journal, 80(1), 85-90.

Nishimura, T., Hattori, A., \& Takahashi, K. (1996). Relationship between degradation of proteoglycans and weakening of the intramuscular connective tissue during post-mortem ageing of beef. Meat Science, 42(3), 251-260.

Nishiumi, T., Fukuda, T., \& Nishimura, T. (1997). Isolation and characterization of a small proteoglycan associated with porcine intramuscular connective tissue. Journal of Agricultural and Food Chemistry, 45(8), 2978-2983.

Oliván, M., Martínez, A., Osoro, K., Sañudo, C. Panea, B., Olleta, J. L. et al. (2004). Effect of muscular hypertrophy on physico-chemical, biochemical and texture traits of meat from yearling bulls. Meat Science, 68(4), 567-575.

Pedersen, M. E., Kolset, S. O., Sorensen, T., \& Eggen, K. H. (1999). Sulfated glycosaminoglycans and collagen in two bovine muscles (m-semitendinosus and m-psoas major) differing in texture. Journal of Agricultural and Food Chemistry, 47(4), 1445-1452.

Purslow, P. P. (1985). The physical basis of meat texture: Observations on the fracture behaviour of cooked bovine $\mathrm{m}$. Semitendinosus. Meat Science, 12(1), 39-60.

Purslow, P. P. (2005). Intramuscular connective tissue and its role in meat quality. Meat Science, 70(3), 435-447.

Purslow, P. P. (2010). Muscle fascia and force transmission. Journal of Bodywork and Movement Therapies, 14(4), 411-417.

Rhee, M. S., Wheeler, T. L., Shackelford, S. D., \& Koohmaraie, M. (2004). Variation in palatability and biochemical traits within and among eleven beef muscles. Journal of Animal Science, 82(2), 534-550.

Rooney, P., \& Kumar, S. (1993). Inverse relationship between hyaluronan and collagens in development and angiogenesis. Differentiation, 54(1), 1-9.

Schmitt, O., Degas, T., Perot, P., Langlois, M. R., \& Dumont, B. L. (1979). Etude morphoanatomique du périmysium (méthodes de description et d'évaluation). Annales De Biologie Animale Biochimie Biophysique, 19(1A), 1-30.

Schmitt, O., \& Dumont, B. L. (1969). Méthodes d'analyse de la structure musculaire Annales De Biologie Animale Biochimie Biophysique, 9(1), 123-134.

Schreurs, N. M., Garcia, F., Jurie, C., Agabriel, J., Micol, D., Bauchart, D., et al. (2008). Meta-analysis of the effect of animal maturity on muscle characteristics in differen muscles, breeds, and sexes of cattle. Journal of Animal Science, 86(11), 2872-2887.

Sifre-Maunier, L., Taylor, R. G., Berge, P., Culioli, J., \& Bonny, J. M. (2006). A globa unimodal thresholding based on probabilistic reference maps for the segmentation of muscle images. Image and Vision Computing, 24(10), 1080-1089.

Stolowski, G. D. Baird, B. E, Miller, R. K, Savell, J. W. Sams, A R, Taylor, J. F, et al. (2006). Factors influencing the variation in tenderness of seven major beef muscles from three angus and brahman breed crosses. Meat Science, 73(3), 475-483.

Torrescano, G., Lujan, L., Sanchez-Escalante, A., Gimenez, B., Roncales, P., \& Beltran, J. A. (2001). Determination of perimysium and endomysium thickness in bovine, ovine and caprine semimembranosus and semitendinosus muscles by video image analysis. In, 47th ICoMST, M. Science (Ed.) (pp. 236-237). Crakovie, Pologne.

Torrescano, G., Sanchez-Escalante, A., Gimenez, B., Roncales, P., \& Beltran, J. A. (2003) Shear values of raw samples of 14 bovine muscles and their relation to muscle collagen characteristics. Meat Science, 64(1), 85-91.

Voermans, N. C., Bonnemann, C. G., Huijing, P. A., Hamel, B. C., van Kuppevelt, T. H., de Haan, A., et al. (2008). Clinical and molecular overlap between myopathies and inherited connective tissue diseases. Neuromuscular Disorders, 18(11), 843-856. 